\title{
Long-standing Valsalva retinopathy
}

\author{
Hirawat Rajshri (1), ${ }^{1}$ Nagesha C Krishnappa, ${ }^{2}$ Unnatti Sharma, ${ }^{3}$ Pratyusha Ganne ${ }^{4}$
}

${ }^{1}$ Vitreo-retina, Gomabai Nethralaya and Research Centre Neemuch, India

${ }^{2} \mathrm{~B}$ W Lions superspeciality Eye Hospital, Bangalore, India ${ }^{3}$ Gomabai Nethralaya and Research Centre, Neemuch, Madhya Pradesh, India ${ }^{4}$ Ophthalmology, All India Institute of Medical Sciences, Guntur, India

Correspondence to Dr Hirawat Rajshri; drrajshreehirawat@gmail.com

Accepted 7 January 2021
Check for updates

(C) BMJ Publishing Group Limited 2021. No commercial re-use. See rights and permissions. Published by BMJ.

To cite: Rajshri H,
Krishnappa NC, Sharma U,
et al. BMJ Case Rep
2021;14:e240812.
doi:10.1136/bcr-2020-
240812

\section{DESCRIPTION}

Valsalva retinopathy occurs due to a sudden rise in intrathoracic pressure (Valsalva maneuver) which is transmitted to the superficial retinal vessels resulting in their rupture. It is often encountered in young and middle-aged people who present with sudden diminution of vision which can vary from a subtle scotoma to total vision loss. We report a case of Valsalva retinopathy where the patient presented very late making the diagnosis challenging and optical coherence tomography (OCT) look interesting.

A 41-year-old man presented with a vision of 20/60 in the right eye. He had no medical problems. He gave a history of heavy weight-lifting 6 weeks earlier. Anterior segment was normal in both eyes. Fundus examination of the right eye showed a semicircular, yellowish premacular lesion which looked like a resolving subhyaloid/subinternal limiting membrane (ILM) haemorrhage (figure 1A). Spectral-domain OCT through fovea revealed a moderately reflective sub-ILM lesion with a central dip suggestive of sedimented blood and foveal dip alike (figure 1B). The left eye was normal. No intervention was carried out anticipating spontaneous resorption. He was advised not to engage in strenuous activities. Since then, he is under close follow-up and is showing a progressive improvement in vision.

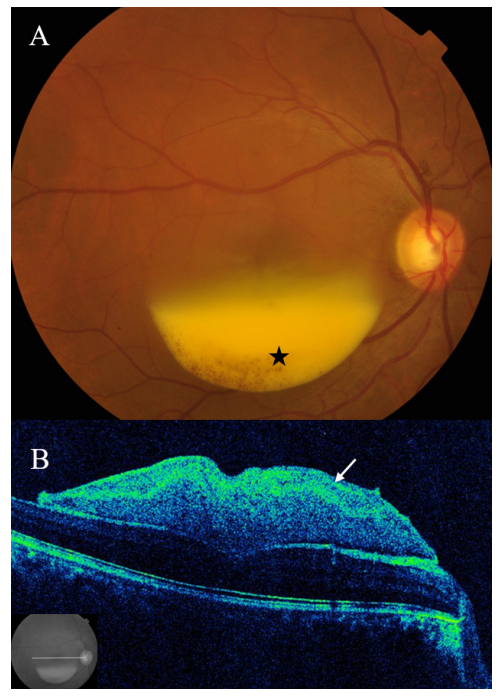

Figure 1 (A) Clinical photograph of the right eye showing a semicircular yellowish deposit in the inferior half of macula (dehemoglobinised premacular blood) (asterisk). (B) OCT through the fovea showing a moderately reflective sub-ILM lesion with a central dip (sedimented plasma mimicking retinal layers) (arrow) and a normal underlying retina. ILM, internal limiting membrane; OCT, optical coherence tomography.
Valsalva retinopathy is characterised by subretinal, subhyaloid, sub-ILM or vitreous haemorrhage. ${ }^{1}$ It may occur unilateral or bilateral. Patients can present with sudden-onset floaters or diminished vision. The presence of haemorrhages in different tissue planes hints at a possible diagnosis of Valsalva retinopathy. Subhyaloid/sub-ILM blood often takes the shape of a boat due to the sedimentation of blood cells in the dependent portion of the bleed. These haemorrhages often resolve spontaneously over a period of time.

The OCT in this patient had appearance of a retinal graft due to the layered sedimentation of the blood components. The yellowish appearance of lesion is due to dehemoglobinisation of the red cells. ${ }^{2}$ Small haemorrhages may resolve spontaneously without any intervention as in present case. Laser hyaloidotomy may be tried in eyes with large subhyaloid haemorrhages over the macula to allow seepage of blood from the subhyaloid space into the vitreous facilitating faster resorption. ${ }^{3}$ Yag laser can be tried even in sub-ILM blood allowing blood into vitreous for faster resorption.

\section{Learning points}

Valsalva retinopathy usually occurs in young to middle-aged people following Valsalva manoeuvres and usually has a good prognosis.

- Minimal subhyaloid/subinternal limiting membrane (ILM) haemorrhage often resolves spontaneously whereas larger subhyaloid/sub-ILM haemorrhages obscuring the macula need laser hyaloidotomy for faster resorption.

- Long-standing haemorrhages may present as yellowish lesions due to the dehemoglobinisation of blood which needs to be differentiated from subretinal location of vitelliform deposits.

Contributors HR: case content. NCK: literature review and manuscript preparation. US: case content PG: script editing and final review.

Funding The authors have not declared a specific grant for this research from any funding agency in the public, commercial or not-for-profit sectors.

Competing interests None declared.

Patient consent for publication Obtained.

Provenance and peer review Not commissioned; externally peer reviewed.

ORCID iD

Hirawat Rajshri http://orcid.org/0000-0003-1490-5970

\section{REFERENCES}

1 Duane TD. Valsalva hemorrhagic retinopathy. Trans Am Ophthalmol Soc 1972;70:298-313.

2 Durukan AH, Kerimoglu H, Erdurman C, et al. Long-term results of Nd:YAG laser treatment for premacular subhyaloid haemorrhage owing to Valsalva retinopathy. Eye 2008;22:214-8.

3 Waikar S, Srivastava VK. Valsalva retinopathy in a young healthy individual. Med J Armed Forces India 2013;69:193-5. 
Images in...

Copyright 2021 BMJ Publishing Group. All rights reserved. For permission to reuse any of this content visit https://www.bmj.com/company/products-services/rights-and-licensing/permissions/

BMJ Case Report Fellows may re-use this article for personal use and teaching without any further permission.

Become a Fellow of BMJ Case Reports today and you can:

- Submit as many cases as you like

- Enjoy fast sympathetic peer review and rapid publication of accepted articles

Access all the published articles

Re-use any of the published material for personal use and teaching without further permission

Customer Service

If you have any further queries about your subscription, please contact our customer services team on +44 (0) 2071111105 or via email at support@bmj.com.

Visit casereports.bmj.com for more articles like this and to become a Fellow 